\title{
Bacteriological examination of Obibia stream during wet and dry seasons in Awka, Anambra State, Nigeria
}

\author{
Gloria Chinelo Ike ${ }^{a}$, Frederick John Chidi Odibo ${ }^{a}$, John Joseph Okeke \\ aDepartment of Applied Microbiology and Brewing, Nnamdi Azikiwe University, Awka, Anambra State, Nigeria.
}

ABSTRACT Diseases caused by contaminated water consumption are among the leading causes of death in children, the elderly, and people who are immunocompromised. Hence there is an important need to ensure that drinking water sources are free from pathogens that can endanger the health of consumers. This study was undertaken to investigate the influence of seasonal changes on the bacteriological distribution of the Obibia stream. A total of 30 water samples ( $500 \mathrm{ml}$ each) were collected for the study at rainy and dry seasons for a period of May to July 2015 and December 2015 to Feb 2016, respectively. Bacteria present in the water samples were isolated and characterized using 16s rDNA sequencing. Total heterotrophic aerobic bacterial counts were determined using standard microbiological biochemical procedures. Their frequencies of occurrence were also determined. Total heterotrophic aerobic bacterial counts $(T H A B C)$ were significantly higher $(P=0.039)>$ total coliform count $>$ fecal coliform counts $>$ Salmonella - Shigella counts $>$ Vibrio counts throughout the periods of sampling in the wet season, with the highest counts obtained in July. THABC was also significantly higher $(P=0.018)$ than other examined bacterial groups and had its peak in January. Bacterial genera present in the examined samples were identified as Shigella, Salmonella, Escherichia coli, Vibrio, Enterobacter, Klebsiella, Enterococcus, Staphylococcus, Pseudomonas, and Serratia with their respective frequencies of occurrence as $4.55 \%, 18.18 \%, 13.64 \%, 27.27 \%, 4.5 \%, 9.09 \%, 4.55 \%, 4.55 \%, 9.09 \%$ and $4.55 \%$ in the wet season. Their respective occurrences in dry season were $4.17 \%, 16.67 \%, 12.50 \%, 25.00 \%, 4.17 \%$, $8.35 \%, 4.17 \%, 8.33 \%, 8.33 \%$, and $8.33 \%$. This bacteriological analysis has shown that wet season samples from the Obibia stream had more bacterial counts than dry seasons. Thus, the water samples from it require further purification steps before being used for domestic purposes by the inhabitants of its surrounding communities.

KEYWORDS: Obibia stream; water assessment; water-borne infections.

Accepted December 12, 2020 Published online January 31, 2021

Cite this article: Ike et al. (2021) Bacteriological Examination of Obibia stream during wet and dry seasons in Awka, Anambra State, Nigeria. Multidisciplinary Science Journal 3: e2021005, doi: 10.29327/multiscience.2021005.

\section{Introduction}

Lakes, rivers, and streams have important multi-usage components such as sources of drinking water, irrigation, fishery, and energy production. With increasing industrialization and population growth, water sources available for various purposes such as drinking, recreation, agriculture, and aquaculture have been adulterated with industrial as well as animal and domestic wastes (Aneja 2005; Ezeabasili et al 2014; Esharegoma et al 2018; Matusala et al 2020; Adamou et al 2020). As a result, it has become the most important means of transmission of several infectious diseases. In Awka, Nigeria (the Anambra State capital), access to adequate urban water supply from the State's water corporation is a serious problem facing the inhabitants since 1999. Hence, to meet their demand for potable water supply, the inhabitants of this State have survived by constructing water supply systems, reservoirs, wells, and boreholes. Others patronize water vendors; rainwater collected from roofs, rivers, and streams. Proliferation in the use of water from alternative sources, like shallow hand-dug wells and boreholes, water from streams and rivers, leads to the utilization of water with questionable qualities for domestic activities. 
River Obibia is a stream (class $\mathrm{H}$ - Hydrographic) in Nigeria (Africa) with the region font code of Africa/Middle East (Awka). It is one of the most important streams in the Awka town alongside the Imo Awka stream. Many residents of the town depend on them for their household water supply and agricultural purposes. Obibia stream is located by the Government Lodge, Amawbia and the Imo Awka River in the Northern part of the town. The vegetation can be classified as the Guinea Savanna because the original forest vegetation has largely been cleared for a range of human activities (Ezenwaji et al 2013). Obibia stream in the East along with other rivers in the town forms the main hydrological features. The Obibia stream is the source of water supply for domestic and agricultural purposes in the Eastern parts of the town. There is a dearth of information on the bacteriological quality of Obibia stream in Awka, Nigeria. This research thus aims to investigate the influence of seasonal changes on the bacteriological load of Obibia stream in Awka, Anambra State, Nigeria.

\section{Material and Methods}

\section{Study Area}

Obibia is a stream (class $\mathrm{H}$ - Hydrographic) in Nigeria with the region font code of Africa/Middle East (Awka). Its coordinates are 6 ${ }^{\circ} 13^{\prime} 60^{\prime \prime} \mathrm{N}$ and $7^{\circ} 9^{\prime} 0^{\prime \prime} \mathrm{E}$ in DMS (Degrees Minutes Seconds) or 6.23333 and 7.15 (in decimal degrees). Obibia stream is situated and surrounded by tributaries from parts of Nibo, Amawbia, Okpalayam, and Awka towns in Awka South Local Government of Anambra State. The Obibia stream is the source of water supply for domestic and agricultural purposes in the eastern parts of the town. Its location is shown in Figure 1.

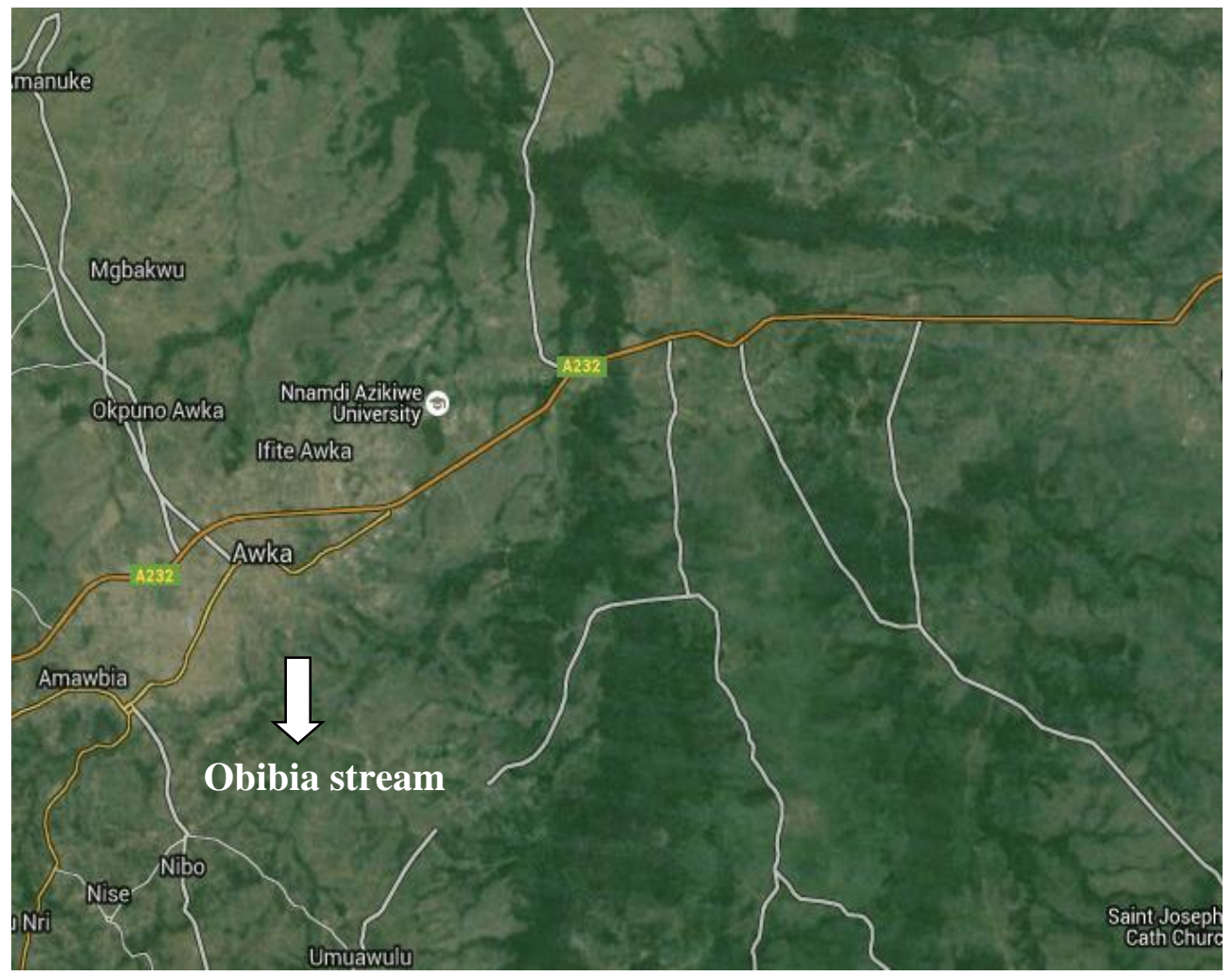

Figure 1 Map showing Obibia stream in Anambra State.

\section{Sample Collection}

A total of 30 freshwater samples from different sampling sources or sites along the Obibia stream were collected from May 2015 to July 2015, which represents the rainy season and December 2015 to February 2016, which represents the dry season. Samples were taken from five different sites in duplicates. The first source (site one) was where washing of bitter leaf, cassava steeping, and processing of other foods was done. Source two was the site for bathing and swimming, source three was situated where run-off from a car wash and block industry entered the water, source four 
was where drinking water was collected and source five was where runoff from steep-sloped agricultural land entered the water. On each occasion, two $500 \mathrm{ml}$ water samples were collected in $1 \mathrm{~L}$ sterile containers from each site.

\section{Microbiological Analysis}

A ten-fold serial dilution of the samples was carried out by adding $1 \mathrm{ml}$ of water samples aseptically into test tubes containing $9 \mathrm{ml}$ of sterile peptone water. Thereafter, $0.1 \mathrm{ml}$ of each diluted sample from tube $10^{-3}$ was cultured on the following media: Nutrient agar (total heterotrophic aerobic bacterial counts (THABC), MacConkey agar (Total coliform counts (TCC), Eosin methylene blue agar (Fecal coliform counts - FCC), Salmonella - Shigella agar (Salmonella - Shigella count - SSC) and Thiocitrate Bile Salt Sucrose agar (Total Vibrio counts - VC) (Cheesbrough 2006).

\section{Characterization of Bacterial Isolates}

Routine microbiological biochemical procedures were used for preliminary characterization and identification of the bacterial isolate according to methods described by Cheesbrough (2006). Isolates were thereafter, confirmed using 16 s rDNA sequencing.

\section{Statistical Analysis}

The data obtained was subjected to one-way ANOVA using Statistical Package for Service Solution (SPSS) 21 for windows evaluation. P-values $<0.05$ were considered significant. Mean partitioning was performed using Tukey test.

\section{Results}

\section{Bacterial counts in wet season}

The total mean plate counts of bacteria isolated from the five sources collected in May, June, and July 2015 of the wet season are presented in Figure 2. The result revealed that there was significant difference $(P<0.05)$ between the THABC, TCC, FCC, SSC, and VC of the samples in each month. The result showed that the THABC, TCC, FCC, and VC in July was significantly $(P<0.05)$ greater than the THABC, TCC, FCC, SSC, and VC in May and June. The results of the present study also revealed that the highest THABC and enteric bacteria were found in July followed by June. The least THABC and enteric bacteria count were found in May.

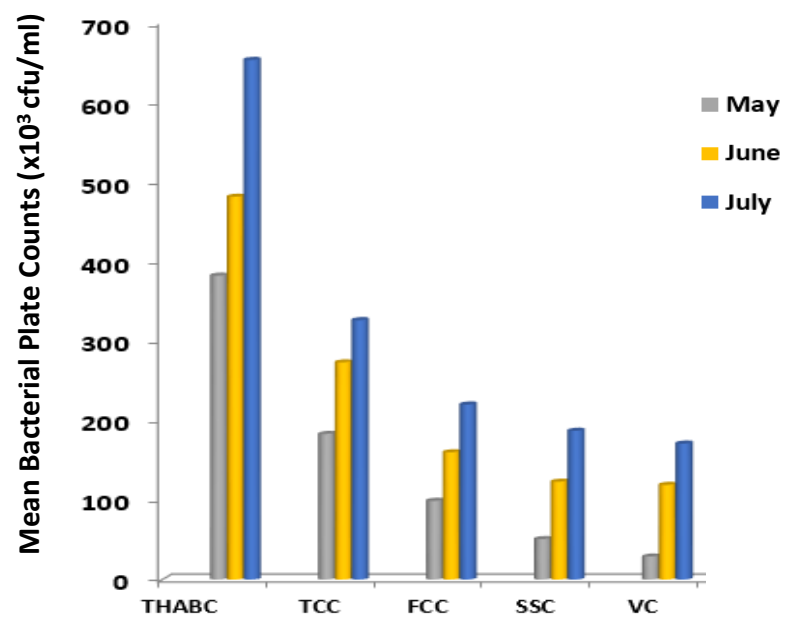

Figure 2 Total mean plate counts of bacteria isolated from the five sources collected in May, June, and July 2015 of the wet season. THABC = Total heterotrophic aerobic bacteria count; TCC = Total coliform count. FCC = Faecal coliform count; SSC = Salmonella Shigella count; $\mathrm{VC}=$ Vibrio count.

\section{Bacterial Counts in Dry Season}

The total mean plate counts of bacteria isolated from the five sources collected in December, January, and February 2015 to 2016 of the dry season are presented in Figure 3. The result revealed that there was significant 
difference $(P<0.05)$ between the THABC, TCC, FCC, SSC, and VC in all of the samples in each month. The result showed that the THABC, TCC, and FCC in December were significantly $(P<0.05)$ greater than the THABC, TCC, and FCC in January and February. The SSC in December was shown to be significantly $(P<0.05)$ greater than the SSC in February and January. The results of the present study also revealed that the highest THABC and enteric bacteria were found in December followed by January. The least THABC and enteric bacterial count were found in February.

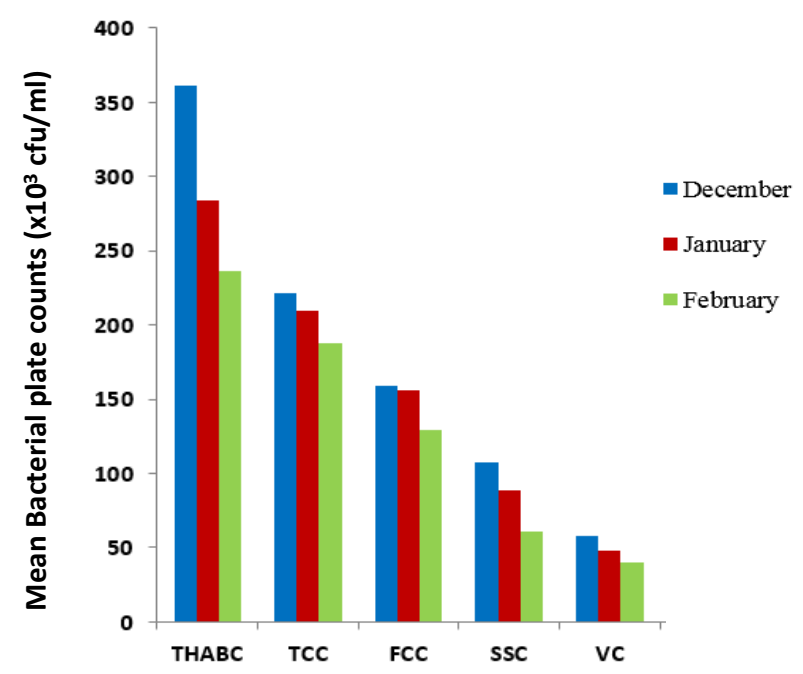

Figure 3 Total mean plate counts of bacteria isolated from the five sources collected in December, January, and February 2015 - 2016 of the dry season. THABC = Total heterotrophic aerobic bacteria count; TCC = Total coliform count. FCC = Faecal coliform count; SSC = Salmonella-Shigella count; VC = Vibrio count.

\section{Prevalence of bacterial isolates in wet season}

The results of the occurrence and frequency of bacteria isolated from samples collected in May, June, and July 2015 of the wet season are shown in Figure 4. The result of the bacteriological analysis revealed the prevalence of 22 isolates of bacteria belonging to the genera: Escherichia coli (13.64\%), Shigella (4.55\%), Salmonella (18.18\%), Vibrio (27.27\%), Enterobacter (4.55\%), Klebsiella (9.09\%), Enterococcus (4.55\%), Staphylococcus (4.55\%), Pseudomonas $(9.09 \%)$ and Serratia (4.55\%). The result of the present study revealed that the highest bacterial occurrences were of the genera Vibrio, Salmonella, and Escherichia coli.

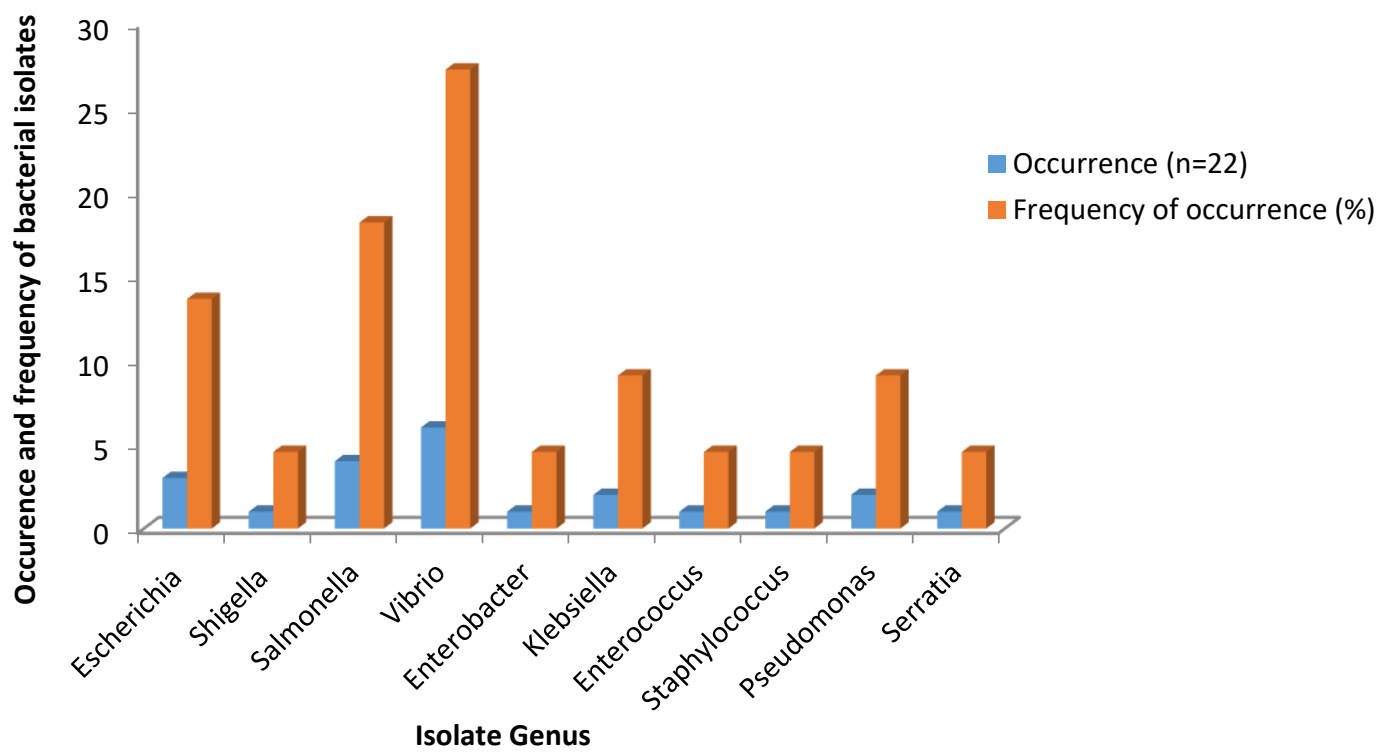

Figure 4 Occurrence and frequency of bacteria isolated from samples collected in May, June, and July 2015 of the wet season. 


\section{Prevalence of bacterial isolates in dry season}

The results of the occurrence and frequency of bacteria isolated from samples collected in December, January, and February 2015 to 2016 of the dry season are shown in Figure 5. The result of the bacteriological analysis revealed the presence of 22 isolates which included bacteria of the genera Escherichia coli (12.50\%), Shigella (4.17\%), Salmonella (16.67\%), Vibrio (25.00\%), Enterobacter (4.17\%), Klebsiella (8.35\%), Enterococcus (4.17\%), Staphylococcus (8.33\%), Pseudomonas (8.33\%) and Serratia (8.33\%). The result of the study showed that the genera of bacteria with the highest occurrence were Vibrio, Salmonella, and Escherichia.

$$
\text { Occurrence }(\mathrm{n}=24) \quad \text { Frequency of occurrence }
$$

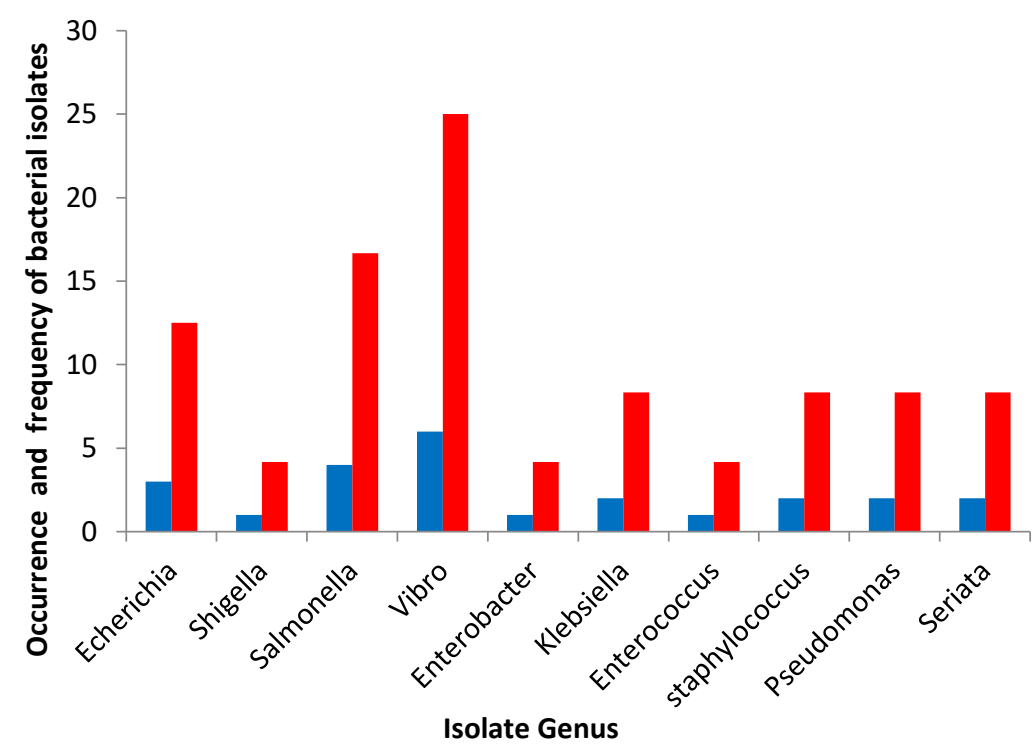

Figure 5 Occurrence and frequency of bacteria isolated from samples collected in December, January, and February 2015 to 2016 of the dry season.

\section{Discussion}

In the present study, the results of the bacteriological analysis of the water samples collected from five sample points each in May, June and July 2015, showed that the bacterial counts for all the water samples were generally high, exceeding the standard limit for drinking water (WHO 2004). The primary sources of these bacteria in the water are animal and human sources based on physical observation. In May 2015, the highest total heterotrophic aerobic bacterial count (THABC) was found in sample 1 and sample 5. The highest total coliform counts (TCC) and fecal coliform counts (FCC) were also found in samples 1 and 5 . This could be attributed to the presence of human activities and runoff from agricultural land containing fecal matter, fertilizers, and other contaminants at the sites where these samples were collected. Human activities include processing of foods like bitter leaf and steeping of cassava. The fermentation of cassava and other carbohydrate-containing foods can increase the population of microorganisms dominating such sites.

A higher number of THABC, TCC and FCC were also obtained at these same sites in June and July. Ezenwaji et al (2016) recorded that increase in biomass of bacteria was as a result of the fermentation of cassava in the cassava steeping site. Similar findings were also reported by different researchers (Shittu et al 2005; Okoli et al 2005). The May study also revealed that the highest Vibrio counts (VC) and Salmonella-Shigella counts (SSC) were found in sample 5 and the lowest SSC and VC were found in sample 4. In June, the highest VC was found in samples 2 and 3 and the least SSC and VC were found in sample 4. In July, the highest VC was found in samples 5 and 2 while the lowest VC was found in samples 4 . These variations could be attributed to the rate and amount of runoff from fecal contaminated land as a result of high precipitation (rainfall) and direct dumping of dirt or defecation in the body of water.

The general comparison of the studies carried out from May to July revealed that the microbial isolates from the samples collected in July were significantly higher than the microbial isolates collected in May and June. The microbial 
isolates from the samples collected in June were as well significantly higher than the microbial isolates collected in May. These findings could be as a result of the change in the level of precipitation (Seasonal variation). More rainfall was observed in July $(150 \mathrm{~mm})$ than in May $(78 \mathrm{~mm})$ and June $(125 \mathrm{~mm})$. The results revealed that precipitation, directly and indirectly, affects the microbial load found in surface waters either by washing off materials from lands (agricultural and non-agricultural land) that could be contaminated or by re-suspending bottoms sediments and other contaminants. According to Okonkwo et al (2008), when precipitation is high, it leads to the generation of bacterial concentrations. Researchers like Efobi (2001) and Ezenwaji and Orgi (2010), reported similar findings which state that high precipitation leads to the generation of high bacterial concentrations in water bodies.

The result in Figure 3 revealed that the highest THABC and enteric bacteria were found in December followed by January. The least THABC and enteric bacteria count was found in February. The result also revealed that there was a seasonal influence on the concentration of the microorganisms found in the samples in each month.

Comparatively, the wet season had more bacteriological counts than the dry season in Obibia stream though not significant ( $P>0.05$ ) using two-tailed paired T- TEST. Both counts exceeded the WHO standard of 2004. This implies that both seasons had almost these effects on the bacteriological status of the Obibia stream. This finding is similar to that obtained by Olatunji et al (2011) and Esharegoma et al (2018), who reported microbial counts from Asa River in llorin and Orogodo River, were more during the rainy season compared to the dry season. This could be attributed to the high runoff of nutrients and debris from land during rainy seasons. Ideally, and following the WHO (2004) recommendations, there should be no bacteria available per $100 \mathrm{ml}$ of the water sample.

The prevalence of the bacterial isolates in both the wet and dry seasons is shown in Figures 4 and 5 . The results of the occurrence and frequency of bacteria isolated from samples collected in May, June, and July 2015 of the wet season are shown in Figure 4. From the result, bacteriological analysis revealed the prevalence of 24 isolates of bacteria belonging to the genera: Escherichia coli (13.64 \%), Shigella (4.55\%), Salmonella (18.18\%), Vibrio (27.27\%), Enterobacter (4.55\%), Klebsiella (9.09\%), Enterococcus (4.55\%), Staphylococcus (4.55\%), Pseudomonas (9.09\%) and Serratia $(4.55 \%)$. The result of the present study revealed that the highest bacterial occurrences were of the genera Vibrio, Salmonella, and Escherichia coli.

The results of the occurrence and frequency of bacteria isolated from samples collected in December, January, and February 2015 to 2016 of the dry season are shown in Figure 5. The result of the bacteriological analysis revealed the presence of 22 isolates which included bacteria of the genera Escherichia (12.50\%), Shigella (4.17\%), Salmonella (16.67\%), Vibrio (25.00 \%), Enterobacter (4.17\%), Klebsiella (8.35\%), Enterococcus (4.17\%), Staphylococcus (8.33\%), Pseudomonas $(8.33 \%)$ and Serratia $(8.33 \%)$. The result of the present study revealed that the highest bacterial occurrences were of the genera Vibrio, Salmonella, and Escherichia coli. The high numbers of Salmonella and Vibrio are not in agreement with EPA water standard for recreational use which states that these pathogenic organisms must not be present in water, because they are of public health significance, having been associated with gastrointestinal infections: diarrhea, dysentery, typhoid fever and other forms of infection (EPA 2003). Other bacterial genera isolated from the water samples are also of public health significance. Staphylococcus aureus is known to produce enterotoxin (Shittu et al 2008). Enterobacter aerogenes is an example of non-fecal coliforms and can be found in vegetation and soil which serves as sources by which pathogens enter the water (Shittu et al 2008). Obiekezie (2006), Obiekezie and Onunkwo (2006), also observed similar findings. The heavy presence of fecal and non-fecal coliforms and pathogens in the water samples generally suggests that a certain section of water may have been contaminated or polluted with feces either of human or animal origin and hence reflect the risk of pathogens present in the water. This result tallied favorably with the report of Banwo (2006), which indicated that the presence of bushes and shrubs makes it likely possible that smaller mammals may have been coming around the water body to drink water, thereby passing out feces into the water. This suggests that the water is not fit for human consumption in its present state.

\section{Conclusion}

Obibia stream has been a source of water for drinking purposes, domestic purposes, and urban agriculture. These activities as important as they are, produce and inject contaminants into the stream. The bacteria indices including 
those of public health significance were high as established in this study as a veritable case of negative human impact in the environment and negative effect of precipitation.

\section{Conflict of Interest}

The authors declare no conflict of interests.

\section{References}

Adamou H, Ibrahim B, Salack S, Adamou R, Sanfo S, Liersch S (2020) Physico-chemical and Bacteriological Quality of Ground Water in a Rural Area of Western Niger: A Case Study of Bonkoukou. Journal of Water and Health 18:77-90.

Aneja KR (2005) Experiment in microbiology plant pathology and biotechnology. $4^{\text {th }}$ ed. New Age International Limited Publishers, New Delhi, pp. 274-275.

Banwo K (2006) Nutrient load and pollution study of some selected stations along Ogunpa River Ibadan, Nigeria. M.Sc. Dissertation, University of Ibadan, Nigeria.

Cheesbrough M (2006) District Laboratory Practice in Tropical Countries-Part 2. $2^{\text {nd }}$ ed. Cambridge University Press, New York, pp. 47-55.

Efobi E (2001) A study of river water pollution at the Nkissi River in Onitsha District of Anambra State. Unpublished M.Sc. Thesis University of Nigeria, Nsukka, Enugu State Nigeria.

Environmental Protection Agency (EPA) (2003) Microorganisms: Water quality act fact sheet. United States Environmental Protection Agency (EPA), USA. pp. 89-234.

Esharegoma OS, Awujo NC, Jonathan I, Nkonye-Asua IP (2018) Microbiological and Physicochemical Analysis of Orogodo River, Agbor, Delta State, Nigeria. International Journal of Ecological Science and Environmental Engineering 5:34-42.

Ezeabasili ACC, Anike OL, Okoro BU, Dominic CM (2014) Arsenic pollution of surface and subsurface water in Onitsha, Nigeria. African Journal of Environmental Science and Technology 8:491-497.

Ezenwaji EE, Eduputa BM, Okoye IO (2016) Investigation into the residential water demand and supply in Enugu Metropolitan Area. American Journal of Water Resources 4: 22-29.

Ezenwaji EE, Orji M (2010) Seasonal fluctuations of microbiological contaminants entering an urban watershed: The case of Asata River in Enugu, Nigeria. Tropical Built Environment Journal 1:1-10.

Matusala G, Amha A, Chala W, Etagegnehu A (2020) Bacteriological Contamination of Drinking Water Supply from Protected Water Sources to Point of use and Water Handling Practices among Beneficiary Households of Boliso Sore Woreda, Wolaita Zone, Ethiopia. International Journal of Microbiology. doi:10.1155/2020/5340202.

Obiekezie SO (2006) Quality characteristics of ground water utilized in Awka, Anambra State, Nigeria. International Journal of Biotechnology and Applied Sciences 1:1-4.

Obiekezie SO, Onunkwo AA (2006) Assessment of chemical and bacteriological contamination of surface water sources in Enugu and its environs. Journal of Applied Sciences 10:210-226.

Okoli GC, Njoko IV, Chukwurah AC, Njoku PC, Njoku JD, Dike MU, Ojieghe RU (2005) Quality characteristics of ground water utilized by resident students of a Nigerian University. Journal of Applied Sciences 5:1088-1091.

Okonkwo IO, Adejoye OD, Ogunnisi TA, Fajobi EA, Shittu OB (2008) Microbiological and physicochemical analysis of different water samples used for domestic purposes in Abeokuta and Ojota, Lagos, Stae, Nigeria. African Journal of Biotechnology 7:617-621.

Olatunji MK, Kolawole TA, Albert BO, Anthony 10 (2011) Assessment of water quality in Asa River (Nigeria) and its indigenous Clarias gariepinus Fish. InternationalJournal of Environmental Research and Public Health 8:4332-4352.

Shittu OB, Olaitan JO, Amusa TS (2008) Physio-chemical and bacteriological analyses of water used for swimming and drinking purposes in Abeokuta, Nigeria. African Journal of Biomedical Resources 11:285-289.

World Health Organization (WHO) (2004) Water, sanitation and hygiene links to Health: Facts and figures. World Health Organization (WHO) Geneva, Switzerland. pp. 31-32. 